\title{
A comparison of medical student competency, attitudes and knowledge of abortion care after a structured clinical curriculum
}

Hallie Gardner

Oregon Health \& Science University Hospital

Marguerite Zimmerman

Oregon Health \& Science University

Moira Flanigan

University of Pennsylvania Perelman School of Medicine

Maureen K Baldwin ( $\nabla$ schaum@ohsu.edu )

Oregon Health and Science University

Research

Keywords: abortion, curriculum, medical student, Ob/Gyn clerkship, education

Posted Date: August 17th, 2020

DOI: https://doi.org/10.21203/rs.2.22383/v2

License: @ (i) This work is licensed under a Creative Commons Attribution 4.0 International License.

Read Full License 


\section{Abstract}

Background: Abortion care is a core educational objective according to the Association of Professors of Gynecology and Obstetrics (APGO), but clinical exposure is variable in medical education. The authors sought to compare professional competency, attitudes, and knowledge regarding abortion between students who attended a structured clinical experience in abortion care to those who chose a lessstructured family planning clinical environment.

Methods: All medical students participating in the Obstetrics \& Gynecology clerkship from 2014-2015 were invited to complete a pre- and post-clerkship survey and grouped based on their attendance to a structured clinical abortion experience at Planned Parenthood (PPCW) versus an alternative Family Planning Clinic (FPC) experience. Self-assessed competency and attitudes about abortion were measured using a 100-mm visual analog scale (VAS). Authors assessed knowledge about abortion with multiplechoice questions.

Results: A total of 89 students completed the surveys (PPCW: 74; FPC: 15). Students attending PPCW were more likely to observe counseling about abortion and ultrasound prior to abortion (PPCW: $67 / 74$, 91\%; FPC: $4 / 15,27 \%, p=<0.01$ ). More PPWC students observed a surgical abortion ( $91 \%$ versus $7 \%$ of FPC students). Self-assessed competency scores improved with composite mean difference in VAS for PPCW of $42.2 \mathrm{~mm}$ and FPC of $27.3 \mathrm{~mm}(\mathrm{p}=0.02)$. Attitude scores were unchanged in those with initial VAS $<80$ $\mathrm{mm}$. Knowledge improved overall, with greater changes among the PPCW group.

Conclusions: A structured clinical abortion experience met APGO educational objectives more than an alternative experience. Future physicians should universally be exposed to clinical abortion care in order to ensure evidence-based education about abortion.

\section{Background}

Most physicians will care for patients who have had an abortion or are in need of this common procedure. ${ }^{1}$ In 2014, approximately 926,200 abortions were performed in the United States. ${ }^{2}$ For comparison, 280,000 appendectomies are performed annually. ${ }^{3}$ Unfortunately, many women face barriers to accessing abortion services, including state-mandated biased, restrictive laws and medically inaccurate counseling. ${ }^{2,4}$ Physicians are a source of inaccurate information and stigmatization about abortion, possibly due to educational gaps. ${ }^{5-8}$

Medical student education has the potential to provide a broad-based understanding of abortion to all future physicians, including medically accurate counseling about abortion and recognition of complications. However, surveys demonstrate that exposure to abortion care during medical school is highly variable, either via lectures or clinical observation. ${ }^{9,10}$ Most medical school curricula for abortion care are set up as "opt-in" programs, where interested students seek out individual experience and training. ${ }^{10}$ Fewer programs include structured clinical experiences in abortion care in the standard 
clerkship schedule, with options to decline all participation ("opt-out") or to decline only direct clinical involvement in abortion ("partial participation"). ${ }^{11,12}$

We hypothesized that a partial participation program during the Ob/Gyn clerkship would result in increased self-assessed competency, attitudes and knowledge about abortion care. We were specifically interested in the effect of a clinical abortion environment on a student's self-reported competence to counsel a patient about what to expect from an abortion. We hypothesized that those who attended a structured clinical experience in abortion care would have increased self-assessed competency by the end of the clerkship, regardless of whether they observed an abortion, compared to those who had ad hoc exposure in a general family planning practice setting.

\section{Methods}

We conducted this pre-post observational cohort study at Oregon Health \& Science University (OHSU) School of Medicine (Portland, OR) in November 2014 through November 2015. The study was approved for a waiver of consent by the OHSU Institutional Review Board. We approached all medical students during the orientation lecture on the first day of their 5-week Obstetrics \& Gynecology clinical clerkship and invited them to complete two optional and anonymous surveys - a pre-clerkship survey on the first day of the rotation and then a post-clerkship survey on the final day of the rotation after the final exam. The surveys included the same core set of competency, attitude, and multiple choice knowledge questions.

\section{Clinical experience groups}

During the study period, the standard clerkship experience in abortion care included a one-hour didactic lecture on abortion and professionalism, including the institution's conscientious objection policy.

Students had pre-selected a clinical abortion care experience, which included either a half-day at the local Planned Parenthood affiliate (Planned Parenthood of the Columbia-Willamette, PPCW) or, alternatively, a half-day in the OHSU outpatient Family Planning Clinic (FPC), in addition to other experiences they may have had during their rotation. At the structured clinical experience at PPCW, students observed patients undergoing all stages of preparation and counseling for a surgical abortion, including the procedure. In the alternative clinical experience at FPC, students participated in family planning visits, which sometimes included uterine aspiration procedures for miscarriage or abortion, but typically consisted of contraception consultations, permanent contraception, medical abortion, and pre-operative visits for first and second trimester surgical abortion. At both clinics, they could choose their level of participation with being in the room for surgical abortion.

We used a $100 \mathrm{~mm}$ Visual Analog Scale (VAS) to ask competency and attitude questions. The VAS is a $100 \mathrm{~mm}$ unmarked line with anchors on either side stating "Definitely No," and "Definitely Yes." Use of the $100 \mathrm{~mm}$ VAS scale allows more statistical comparison than a Likert Scale and is validated for many 
types of questions, including anxiety, pain, and attitudes. ${ }^{13-15}$ Respondents were advised to make a single perpendicular mark on the line. Individual responses were averaged into a mean composite score for three VAS questions regarding competency and four questions assessing student attitudes regarding abortion and abortion education. We assessed the proportion of correct responses to five knowledge questions with multiple correct answer choices. We expected improvement in both groups, with group differences mainly for questions related to clinical procedures.

Data management and statistical analysis

We based our sample size calculation on an anticipated mean response on the post-clerkship survey to the following self-assessed competency question, "I could adequately counsel a patient about what to expect from an abortion." We estimated $90 \mathrm{~mm}$ in the clinical abortion care attendance group and $60 \mathrm{~mm}$ in the non-attendance group, with a standard deviation of approximately $30 \mathrm{~mm}$ for each group. We chose these estimates by pilot-testing the question with students. We estimated that approximately $75 \%$ of students would attend the clinical abortion experience. Therefore, we planned to obtain completed surveys for at least 32 subjects in the attendance group and 11 in the non-attendance group to show a significant difference between group means using a one-sided t-test with $80 \%$ power and alpha of $p<0.05$.

We managed data using REDCap electronic data capture tools hosted at OHSU. REDCap (Research Electronic Data Capture) is a secure web-based application designed to support data capture for research studies. ${ }^{16}$ Paper surveys were batched for data entry at two time-points to ensure anonymity. Data were then exported for analysis in STATA/IC 14.2 (StataCorp LP, College Station, TX). Data were analyzed using t-test for means and chi-square test of proportions as well as non-parametric tests where appropriate.

\section{Results}

Eighty-nine of 123 students (72\%) provided responses to the pre and post-clerkship surveys. The majority attended PPCW $(74 / 89,83 \%)$ and 15/89 (17\%) attended FPC. A majority of students who attended the structured experience at PPCW participated in abortion care $(67 / 74 ; 91 \%)$, including patient counseling, ultrasound, surgical abortion procedure, and examination of the products of conception to evaluate complete uterine evacuation (Table 1). Only four of the fifteen (27\%) FPC students observed any part of abortion care, which was patient counseling and ultrasound $(4 / 15 ; 27 \%)$ and observation of the surgical abortion $(1 / 15 ; 7 \%)$.

Table 2 shows the mean response of $100 \mathrm{~mm}$ VAS pre- and post-clerkship surveys regarding competence and attitude. Attitude scores among all students prior to the clerkship were mostly high, in support of abortion education with a mean VAS of $90.2 \mathrm{~mm}$ and $80.9 \mathrm{~mm}$ among PPWC and FPC students respectively. Attitudes around abortion education in medical training, the ability of patients to access 
abortion and willingness to refer patients to abortion providers did not vary between either group after their clinical experiences, though scores to all questions had a mean VAS $>60 \mathrm{~mm}$ prior to the clerkship.

Individual self-assessed competency questions increased over time for both groups, with larger increased VAS response for the questions about feeling adequate to counsel a patient about what to expect from an abortion (13 mm difference in increase between groups, $p=0.03$ ) and about feeling adequate to explain all options to a patient with an unintended pregnancy $(23 \mathrm{~mm} ; \mathrm{p}<0.01)$. There was not a significant difference in increase over time between the two groups in their response to feeling knowledgeable enough to discuss abortion with patients $(9 \mathrm{~mm} ; \mathrm{p}=0.11)$.

The PPCW group had a significant increase in composite competency on the $100 \mathrm{~mm}$ VAS score (28.1 $\mathrm{mm}$ to $71.5 \mathrm{~mm}$ for PPCW versus $34.7 \mathrm{~mm}$ to $62.0 \mathrm{~mm}$ for FPC; difference of means of $42.2 \mathrm{~mm}$ and $27.3 \mathrm{~mm}$ respectively, $\mathrm{p}=0.02$ ). Pre-clerkship competency self-evaluation was higher among the FPC cohort, yet that group reported a smaller change and lower overall competency following their clinical experience.

Nineteen students had an initial composite attitude score less than $80 \mathrm{~mm}$, eight of whom observed an abortion. Self-perceived competence increased in all but one of these students, independent of attendance. However, of those with low initial composite attitude who attended PPCW $(n=11)$, there was a mean $43.4 \mathrm{~mm}$ increase on the competence VAS, compared to only a mean $27.1 \mathrm{~mm}$ increase in those who did not attend $(n=8 ; p=0.08)$.

No students responded correctly to all knowledge question answer choices on either the pre- or postclerkship surveys (Table 3 ). Following the clerkship, 59/74 (80\%) of PPCW attendees and 9/15 (60\%) of FPC group correctly identified that $50 \%$ of pregnancies in the US are unintended $(p=0.1)$, which was improved by $20 \%$ of PPCW participants from baseline but unchanged in the FPC group. More students in both groups could identify that all types of contraception can be initiated immediately following a surgical abortion: $35 \%$ to $57 \%$ for PPCW and $20 \%$ to $40 \%$ for FPC ( $p=0.24)$. We observed improvement across all domains for students in both clinical experiences, though with notable differences in the proportion of correct responses related to aspects of the procedures, such as methods of confirmation that the abortion is complete.

\section{Discussion}

We found that medical student self-perceived level of competence in providing accurate information regarding abortion procedures and effectively counseling future patients about all options related to terminating a pregnancy improved for all students after a comprehensive abortion curriculum, regardless of their participation in clinical abortion. However, composite measures of self-perceived competence increased significantly more for those who participated in a structured clinical abortion experience, compared to ad hoc clinical abortion experience, regardless whether they observed an abortion. 
We had expected at least a $30 \mathrm{~mm}$ improvement in the composite competence measure to be meaningfully different. While the mean difference was statistically significant, we only observed a $15 \mathrm{~mm}$ difference in increase of self-reported composite competence between the two groups and a $9 \mathrm{~mm}$ absolute difference, which was not statistically different. This may be explained by the relatively higher baseline competence in "explaining all options to a patient who has an unintended pregnancy" reported by the FPC group.

Despite consistently large changes in self-reported competency, there were minimal changes to group attitudes about abortion. Our findings lead us to conclude that it is possible to provide medical student education about abortion while recognizing that some students may have strong moral beliefs that oppose abortion. Varying levels of participation in a clinical environment focused on abortion care may increase a future medical provider's ability to administer medically accurate information to their patients.

The limitations of this study include a small sample size, and the selection bias inherent in a study dependent on self-reported surveys and self-selection into educational experiences. Most importantly, because we relied on self-evaluation of competence to be able to explain procedures and options, we did not evaluate the quality of the counseling that would occur from these future physicians. Students who self-selected into a non-structured clinical abortion experience (FPC) due to wanting to avoid exposure to abortion may have inflated views of their ability to provide non-directive medically accurate counseling and expectations about options. As a group, they scored lower on knowledge questions, particularly regarding aspects of the procedure that would be important components of their counseling. A strength of this study is that we grouped students based on the educational environment that they attended and separately assessed the educational exposures that actually occurred.

Both the Association of Professors of Gynecology and Obstetrics (APGO) and the American College of Obstetricians and Gynecologists (ACOG) recommend that all medical school curricula include training in family planning, including contraception and abortion care. ${ }^{17}$ Learning about abortion is a core educational objective according to APGO, which sets national standards for medical student education. ${ }^{18}$ The four objectives related to abortion that students are expected to learn are: (A) Provide non-directive counseling to patients surrounding pregnancy including unintended pregnancy; (B) List surgical and nonsurgical methods of pregnancy termination; (C) Identify potential complications of pregnancy termination; and (D) Describe the public health impact of the legal status of abortion. However, medical students are frequently not provided with education to meet these objectives. $., 10,19$

A 2009 study of medical schools in the US and Canada reported that $67 \%$ included an abortion lecture in the preclinical curricula. ${ }^{9}$ The remaining $33 \%$ did not include any discussion of abortion procedures, pregnancy options counseling, post-abortion care, or abortion law/policy/availability in their curriculum. A survey of Ob/Gyn medical student clerkship directors showed that $17 \%$ of programs had no formal abortion education and $55 \%$ did not offer clinical training or exposure. ${ }^{10}$ Students receive inconsistent abortion education. In 2009 , only $24 \%$ of medical students at the University of Colorado reported clinical exposure to abortion and $57 \%$ did not have any formal didactic training in abortion. ${ }^{19}$ 
Family planning educational curricula is well received by medical students. ${ }^{20-22}$ After the University of New Mexico School of Medicine instituted a preclinical and clinical abortion curriculum with an optional clinical training opportunity, $96 \%$ of students surveyed reported that abortion was an appropriate topic for medical school education and $84 \%$ of the students who participated in the clinical training experience reported it was very important to their education. ${ }^{21}$

Ob/Gyn residents who morally object to performing abortions can undergo partial participation in abortion training up to their level of comfort at many institutions, a practice shown to improve knowledge, capability, and the improved ability to care for patients with miscarriage. ${ }^{11,23}$

We found that when a partial participation format is applied to undergraduate medical education with structured access to clinical abortion, a larger proportion of students are exposed to abortion education, regardless of chosen specialty training, potentially increasing knowledge and professionalism among future healthcare providers.

\section{Conclusions}

Learning about abortion medical care is a core educational objective according to the Association of Professors of Gynecology and Obstetrics (APGO). We assessed medical student self-assessed competency, attitudes, and knowledge about abortion medical care before and after a partial participation program in clinical abortion during the Ob/Gyn clerkship. Those who participated in a structured clinical abortion environment, at a local Planned Parenthood affiliate, experienced increased competency, attitudes and knowledge scores, compared to those who attended a family planning clinic not primarily focused on abortion. In particular, the structured clinical abortion environment resulted in an increase in the student's self-reported competence to counsel a patient about what to expect from an abortion, regardless whether they observed an abortion. We demonstrate that students report that partial participation programs are appropriate regardless of moral beliefs and that a structured clinical abortion environment provides more effective learning outcomes, even with partial participation.

\section{List Of Abbreviations}

APGO: Association of Professors of Gynecology and Obstetrics; VAS: Visual Analog Scale; OHSU: Oregon Health \& Science University; PPCW: Planned Parenthood of the Columbia-Willamette; FPC: Family Planning Clinic; ACOG: American College of Obstetricians and Gynecologists

\section{Declarations}

Ethics approval and consent to participate: The study was approved for a waiver of consent by the OHSU Institutional Review Board.

Consent for publication: Not applicable 
Availability of data and materials: The datasets generated and analyzed during this study are not publicly available due to potential breach of privacy, but are available from the corresponding author on reasonable request.

Competing interests: The authors declare that they have no competing interests.

Funding/Support: The authors report no external funding source for this study. Oregon Clinical Trials Research Institute at OHSU receives funding (UL1TR002369) for hosting Research Electronic Data Capture tools.

Authors contributions: HG designed the study, created data collection instruments, collected primary data, contributed to the manuscript writing, and reviewed the final manuscript. MZ performed final data analysis and edited the manuscript. MF wrote portions of the manuscript, created tables, and reviewed the final manuscript. MB provided mentorship and supervision for IRB submission, protocol development, manuscript writing and editing, and reviewed and revised the final manuscript.

Acknowledgements: The authors wish to thank the OHSU Ob/Gyn clerkship director and coordinator.

Author's information: $\mathrm{HG}$ is a community $\mathrm{Ob} / \mathrm{Gyn}$ in Portland, $\mathrm{OR}$ and former student and resident at OHSU. MZ is a current OHSU medical student. MF is a former OHSU medical student and current resident at University of Pennsylvania Health System in Internal Medicine/Neurology. MB is Associate Professor in the Department of Ob/Gyn at OHSU in Portland, OR.

\section{References}

1. Jones RK, Jerman J. Population Group Abortion Rates and Lifetime Incidence of Abortion: United States, 2008-2014. Am J Public Health 2017;107:1904-9.

2. Jones RK, Jerman J. Abortion Incidence and Service Availability In the United States, 2014. Perspect Sex Reprod Health 2017;49:17-27.

3. Livingston EH, Woodward WA, Sarosi GA, Haley RW. Disconnect between incidence of nonperforated and perforated appendicitis: implications for pathophysiology and management. Ann Surg 2007;245:886-92.

4. Committee on Health Care for Underserved Women. ACOG Committee Opinion No. 613: Increasing access to abortion. Obstet Gynecol 2014;124:1060-5.

5. Aksel S, Fein L, Ketterer E, Young E, Backus L. Unintended consequences: abortion training in the years after Roe v Wade. Am J Public Health 2013;103:404-7.

6. Coles MS, Makino KK, Phelps R. Knowledge of medication abortion among adolescent medicine providers. J Adolesc Health 2012;50:383-8.

7. Stulberg DB, Dude AM, Dahlquist I, Curlin FA. Abortion provision among practicing obstetriciangynecologists. Obstet Gynecol 2011;118:609-14. 
8. Dodge LE, Haider S, Hacker MR. Attitudes toward Abortion among Providers of Reproductive Health Care. Womens Health Issues 2016;26:511-6.

9. Steinauer J, LaRochelle F, Rowh M, Backus L, Sandahl Y, Foster A. First impressions: what are preclinical medical students in the US and Canada learning about sexual and reproductive health? Contraception 2009;80:74-80.

10. Espey E, Ogburn T, Chavez A, Qualls C, Leyba M. Abortion education in medical schools: a national survey. Am J Obstet Gynecol 2005;192:640-3.

11. Steinauer JE, Turk JK, Preskill F, Devaskar S, Freedman L, Landy U. Impact of partial participation in integrated family planning training on medical knowledge, patient communication and professionalism. Contraception 2014;89:278-85.

12. Turk JK, Preskill F, Fields A, Landy U, Steinauer JE. Exploring How Residents Who Partially Participate in Family Planning Training Determine Their Level of Participation. Womens Health Issues 2017;27:614-9.

13. Jensen MP, Chen C, Brugger AM. Interpretation of visual analog scale ratings and change scores: a reanalysis of two clinical trials of postoperative pain. J Pain 2003;4:407-14.

14. DeLoach LJ, Higgins MS, Caplan AB, Stiff JL. The visual analog scale in the immediate postoperative period: intrasubject variability and correlation with a numeric scale. Anesth Analg 1998;86:102-6.

15. Facco E, Stellini E, Bacci C, et al. Validation of visual analogue scale for anxiety (VAS-A) in preanesthesia evaluation. Minerva Anestesiol 2013;79:1389-95.

16. Harris PA, Taylor R, Thielke R, Payne J, Gonzalez N, Conde JG. Research electronic data capture (REDCap)-a metadata-driven methodology and workflow process for providing translational research informatics support. J Biomed Inform 2009;42:377-81.

17. Committee on Health Care for Underserved Women. ACOG Committee opinion no. 612: Abortion training and education. Obstet Gynecol 2014;124:1055-9.

18. Association of Professors of Gynecology and Obstetrics. APGO Medical Student Educational Objectives. https://www.apgo.org/wp-content/uploads/2016/05/APGO-Med-Student-Obj-10-Ed-.pdf. Accessed November 22, 2019.

19. Tocce K, Sheeder J, Vontver L. Failure to achieve the association of professors in gynecology and obstetrics objectives for abortion in third-year medical student curriculum. J Reprod Med 2011;56:474-8.

20. Espey E, Ogburn T, Dorman F. Student attitudes about a clinical experience in abortion care during the obstetrics and gynecology clerkship. Acad Med 2004;79:96-100.

21. Espey E, Ogburn T, Leeman L, Nguyen T, Gill G. Abortion education in the medical curriculum: a survey of student attitudes. Contraception 2008;77:205-8.

22. Guiahi M, Maguire K, Ripp ZT, Goodman RW, Kenton K. Perceptions of family planning and abortion education at a faith-based medical school. Contraception 2011;84:520-4. 
23. Steinauer JE, Hawkins M, Turk JK, Darney P, Preskill F, Landy U. Opting out of abortion training: benefits of partial participation in a dedicated family planning rotation for ob-gyn residents. Contraception 2013;87:88-92.

\section{Tables}

\section{Table 1}

Characteristics of medical student respondents surveyed following a clinical clerkship in Obstetrics \& Gynecology.

\begin{tabular}{|c|c|c|}
\hline \multirow[t]{2}{*}{ Characteristic, $\mathrm{n}$} & PPCWa $^{a}$ & $\mathrm{FPC}^{\mathrm{b}}$ \\
\hline & $n=74$ & $n=15$ \\
\hline \multirow{3}{*}{$\begin{array}{l}\text { Mean age (range) } \\
\text { Reported gender (\%) } \\
\text { Female } \\
\text { Male } \\
\text { Intended medical specialty (\%) } \\
\text { Primary care or Ob/Gyn } \\
\text { Pediatrics/medicine/ED } \\
\text { Surgical specialty/other/undecided } \\
\text { Reported educational experiences (\%) } \\
\text { Didactic lecture } \\
\text { Patient counseling about abortion } \\
\text { Ultrasound prior to abortion } \\
\text { Surgical abortion procedure } \\
\text { Examination of products of conception }\end{array}$} & $\begin{array}{l}28.6(24-39) \\
39(52.7) \\
35(47.3)\end{array}$ & $\begin{array}{l}29.2(26-35) \\
8(53.3) \\
7(46.7)\end{array}$ \\
\hline & $\begin{array}{l}26(35.1) \\
18(24.3) \\
30(40.5)\end{array}$ & $\begin{array}{l}5(33.3) \\
4(26.7) \\
6(40.0)\end{array}$ \\
\hline & $\begin{array}{l}56(75.7) \\
67(90.5) \\
67(90.5) \\
67(90.5) \\
67(90.5)\end{array}$ & $\begin{array}{l}10(66.7) \\
4(26.7) \\
4(26.7) \\
1(6.7) \\
0\end{array}$ \\
\hline \multicolumn{3}{|c|}{$\begin{array}{l}\text { a Students who attended a structured clinical abortion experience at Planned Parenthood of the } \\
\text { Columbia-Willamette (PPCW) }\end{array}$} \\
\hline
\end{tabular}


Table 2

Mean $100 \mathrm{~mm}$ Visual Analog Score (VAS) prior to (pre) and following (post) the clerkship.

\begin{tabular}{|c|c|c|c|c|c|}
\hline \multirow[t]{2}{*}{ Mean VAS response in $\mathrm{mm}$ (SD) } & \multicolumn{4}{|c|}{ PPCW $(n=74)^{a}$ FPC $(n=15)^{b}$} & \multirow{2}{*}{$\begin{array}{l}\mathrm{p}- \\
\text { value }\end{array}$} \\
\hline & Pre & Post & Pre & Post & \\
\hline $\begin{array}{l}\text { Attitude } \\
\text { Abortion care is an appropriate topic for medical school curriculum } \\
\text { Clinical experience in abortion care is important to offer during } \\
\text { medical school } \\
\text { Women should be able to choose to have an abortion } \\
\text { I would be willing to refer patients inquiring about abortion to other } \\
\text { clinics or providers if necessary }\end{array}$ & $\begin{array}{l}90.2 \\
(15.7) \\
85.8 \\
(18.4) \\
90.0 \\
(18.2) \\
89.9 \\
(20.4)\end{array}$ & $\begin{array}{l}90.8 \\
(15.8) \\
88.1 \\
(18.3) \\
90.2 \\
(17.9) \\
91.9 \\
(15.6)\end{array}$ & $\begin{array}{l}80.9 \\
(21.1) \\
63.4 \\
(26.4) \\
69.9 \\
(34.5) \\
87.9 \\
(25.0)\end{array}$ & $\begin{array}{l}73.7 \\
(27.1) \\
68.8 \\
(31.3) \\
72.7 \\
(35.2) \\
89.1 \\
(25.4)\end{array}$ & $\begin{array}{l}<0.01 \\
<0.01 \\
<0.01 \\
0.58\end{array}$ \\
\hline Composite attitude & $\begin{array}{l}89.1 \\
(15.5)\end{array}$ & $\begin{array}{l}90.3 \\
(16.2)\end{array}$ & $\begin{array}{l}75.6 \\
(22.1)\end{array}$ & $\begin{array}{l}76.1 \\
(22.4)\end{array}$ & $<0.01$ \\
\hline Mean difference (post-pre) & $1.04(7$ & & $0.53(7$ & & 0.81 \\
\hline & $\begin{array}{l}31.4 \\
(26.5)\end{array}$ & $\begin{array}{l}69.4 \\
(17.3)\end{array}$ & $\begin{array}{l}32.3 \\
(20.1)\end{array}$ & $\begin{array}{l}61.7 \\
(15.8)\end{array}$ & $\begin{array}{l}0.12 \\
0.01\end{array}$ \\
\hline $\begin{array}{l}\text { I could adequately counsel a patient about what to expect from an } \\
\text { abortion } \\
\text { I could adequately explain all options to a patient who has an } \\
\text { unintended pregnancy }\end{array}$ & $\begin{array}{l}24.3 \\
(22.6) \\
30.6 \\
(23.9)\end{array}$ & $\begin{array}{l}70.6 \\
(17.5) \\
72.9 \\
(19.1)\end{array}$ & $\begin{array}{l}24.5 \\
(20.1) \\
47.4 \\
(26.2)\end{array}$ & $\begin{array}{l}57.7 \\
(19.1) \\
66.7 \\
(16.0)\end{array}$ & 0.24 \\
\hline Composite competency & $\begin{array}{l}28.8 \\
(22.6)\end{array}$ & $\begin{array}{l}71.0 \\
(16.6)\end{array}$ & $\begin{array}{l}34.7 \\
(19.2)\end{array}$ & $\begin{array}{l}62.0 \\
(15.5)\end{array}$ & 0.06 \\
\hline Mean difference (post-pre) & $42.2(2$ & 21.3) & $27.3(2$ & & 0.02 \\
\hline \multicolumn{6}{|c|}{$\begin{array}{l}\text { astudents who attended a structured clinical abortion experience at Planned Parenthood of the } \\
\text { Columbia-Willamette (PPCW) }\end{array}$} \\
\hline \multicolumn{6}{|c|}{$\begin{array}{l}\text { bStudents who attended an alternative ad hoc exposure to clinical abortion care at a University Family } \\
\text { Planning Clinic (FPC). }\end{array}$} \\
\hline
\end{tabular}

Table 3. Medical student responses to knowledge questions about abortion before and after they participated versus opted-out of a structured clinical experience in abortion care. Correct responses including for multiple choice answer stems are included. Correct answer choices are in bold. P-value is for chi-square test of proportions, comparing PPCW and FPC groups on the Post-test survey. 


\begin{tabular}{|c|c|c|c|c|c|}
\hline & \multirow{2}{*}{\multicolumn{2}{|c|}{ PPCW $(n=74)$}} & \multicolumn{2}{|c|}{ FPC $(n=15)$} & \multirow{2}{*}{$\begin{array}{l}\mathrm{p}- \\
\text { value }\end{array}$} \\
\hline & & Post & Pre & Post & \\
\hline $\begin{array}{l}\text { What percentage of pregnancies in the United } \\
\text { States are unintended?(circle one) } 30 \% ; 40 \% \text {; } \\
50 \% \cdot 60 \% .70 \%\end{array}$ & $\begin{array}{l}45 \\
(60.8)\end{array}$ & $\begin{array}{l}59 \\
(79.7)\end{array}$ & $\begin{array}{l}9 \\
(60.0)\end{array}$ & \begin{tabular}{|l}
9 \\
$(60.0)$
\end{tabular} & \\
\hline $\begin{array}{l}\text { What types of contraception can be started } \\
\text { immediately following a surgical abortion? } \\
\text { (circle all that apply) }\end{array}$ & $\begin{array}{l}26 \\
(35.1)\end{array}$ & $\begin{array}{l}42 \\
(56.8)\end{array}$ & $\begin{array}{l}3 \\
(20.0)\end{array}$ & $\begin{array}{l}6 \\
(40.0)\end{array}$ & 0.24 \\
\hline Combined oral contraceptive pills (OCPs) & $\begin{array}{l}50 \\
(67.6)\end{array}$ & $\begin{array}{l}63 \\
(85.1)\end{array}$ & $\begin{array}{l}9 \\
(60.0)\end{array}$ & $\begin{array}{l}13 \\
(86.7)\end{array}$ & 0.88 \\
\hline Progestin only pills (POPs) & $\begin{array}{l}49 \\
(66.2)\end{array}$ & $\begin{array}{l}63 \\
(85.1)\end{array}$ & $\begin{array}{l}8 \\
(53.3)\end{array}$ & $\begin{array}{l}11 \\
(73.3)\end{array}$ & 0.27 \\
\hline Nuva Ring (vaginal ring) & $\begin{array}{l}37 \\
(50.0)\end{array}$ & $\begin{array}{l}45 \\
(60.8)\end{array}$ & $\begin{array}{l}5 \\
(33.3)\end{array}$ & $\begin{array}{l}99 \\
(60.0)\end{array}$ & 0.95 \\
\hline Depo Provera & $\begin{array}{l}55 \\
(74.3)\end{array}$ & $\begin{array}{l}63 \\
(85.1) \\
\end{array}$ & $\begin{array}{l}9 \\
(60.0)\end{array}$ & $\begin{array}{l}99 \\
(60.0)\end{array}$ & 0.02 \\
\hline IUD (Mirena or Paragard) & $\begin{array}{l}53 \\
(71.6)\end{array}$ & $\begin{array}{l}62 \\
(83.8)\end{array}$ & $\begin{array}{l}6 \\
(40.0)\end{array}$ & $\begin{array}{l}12 \\
(80.0) \\
\end{array}$ & 0.72 \\
\hline Implant (Nexplanon) & $\begin{array}{l}56 \\
(75.7) \\
\end{array}$ & $\begin{array}{l}67 \\
(90.5) \\
\end{array}$ & $\begin{array}{l}13 \\
(86.7) \\
\end{array}$ & $\begin{array}{l}11 \\
(73.3) \\
\end{array}$ & 0.07 \\
\hline $\begin{array}{l}\text { Before a first trimester surgical abortion in } \\
\text { Oregon, standard of care is to complete which of } \\
\text { the following? (circle all that apply) }\end{array}$ & 0 & 0 & 0 & 0 & - \\
\hline Abdominal ultrasound & $\begin{array}{l}37 \\
(50.0)\end{array}$ & $\begin{array}{l}24 \\
(32.4)\end{array}$ & $\begin{array}{l}4 \\
(26.7)\end{array}$ & $\begin{array}{l}7 \\
(46.7)\end{array}$ & 0.29 \\
\hline Transvaginal ultrasound & $\begin{array}{l}31 \\
(41.9)\end{array}$ & $\begin{array}{l}58 \\
(78.4)\end{array}$ & $\begin{array}{l}7 \\
(46.7)\end{array}$ & $\begin{array}{l}10 \\
(66.7)\end{array}$ & 0.33 \\
\hline Blood count (Hematocrit/Hemoglobin) & $\begin{array}{l}47 \\
(63.5)\end{array}$ & $\begin{array}{l}3 \\
(58.1)\end{array}$ & 8 & $\begin{array}{l}10 \\
(66.7)\end{array}$ & 0.54 \\
\hline Confirm Rh status & $\begin{array}{l}32 \\
(43.2)\end{array}$ & $\begin{array}{l}62 \\
(83.8)\end{array}$ & $\begin{array}{l}3 \\
(20.0)\end{array}$ & $\begin{array}{l}10 \\
(66.7)\end{array}$ & 0.12 \\
\hline Type \& Screen & $\begin{array}{l}35 \\
(47.3)\end{array}$ & $\begin{array}{l}34 \\
(46.0)\end{array}$ & $\begin{array}{l}6 \\
(40.0)\end{array}$ & $\begin{array}{l}8 \\
(53.3)\end{array}$ & 0.60 \\
\hline NPO status for 8 hours prior to $\mathrm{r}$ & $\begin{array}{l}28 \\
(37.8)\end{array}$ & $\begin{array}{l}17 \\
(23.0)\end{array}$ & $\begin{array}{l}7 \\
(46.7)\end{array}$ & $\begin{array}{l}11 \\
(73.3)\end{array}$ & $<0.01$ \\
\hline Parental permission if under age 18 & $\begin{array}{l}15 \\
(20.3)\end{array}$ & 0 & $\begin{array}{l}3 \\
(20.0)\end{array}$ & \begin{tabular}{|l|}
1 \\
$(6.7)$
\end{tabular} & 0.03 \\
\hline $\begin{array}{l}\text { After a first trimester surgical abortion, what } \\
\text { steps are routinely taken to verify if the } \\
\text { procedure is complete? (circle all that apply) }\end{array}$ & 0 & 0 & 0 & 0 & - \\
\hline Ultrasound & $\begin{array}{l}34 \\
(46.0)\end{array}$ & $\begin{array}{l}10 \\
(13.5)\end{array}$ & $\begin{array}{l}10 \\
(66.7)\end{array}$ & $\begin{array}{l}7 \\
(46.7)\end{array}$ & $<0.01$ \\
\hline $\begin{array}{r}\text { Examination of the tissue (products of } \\
\text { conception) }\end{array}$ & $\begin{array}{l}56 \\
(75.7)\end{array}$ & $\begin{array}{l}73 \\
(98.7)\end{array}$ & $\begin{array}{l}10 \\
(66.7)\end{array}$ & $\begin{array}{l}12 \\
(80.0) \\
\end{array}$ & $<0.01$ \\
\hline Tissue sent to pathology & $\begin{array}{l}31 \\
(41.9)\end{array}$ & $\begin{array}{l}8 \\
(10.8)\end{array}$ & $\begin{array}{l}5 \\
(33.3) \\
\end{array}$ & $\begin{array}{l}8 \\
(53.3) \\
\end{array}$ & $<0.01$ \\
\hline Serial measurement of beta hCG & $\begin{array}{l}37 \\
(50.0)\end{array}$ & $\begin{array}{l}13 \\
(17.6)\end{array}$ & $\begin{array}{l}7 \\
(46.7) \\
\end{array}$ & $\begin{array}{ll}10 \\
(66.7)\end{array}$ & $<0.01$ \\
\hline $\begin{array}{l}\text { Which of the following are true regarding } \\
\text { complications of first trimester surgical } \\
\text { abortion? (circle all that apply) }\end{array}$ & 0 & 0 & 0 & 0 & - \\
\hline $\begin{array}{r}\text { The most common complications following a first } \\
\text { trimester abortion include need for reaspiration, } \\
\text { incomplete abortion, bleeding, infection, and } \\
\text { uterine perforation }\end{array}$ & $\begin{array}{l}50 \\
(67.6)\end{array}$ & $\begin{array}{l}65 \\
(87.8)\end{array}$ & $\begin{array}{l}10 \\
(66.7)\end{array}$ & $\begin{array}{l}9 \\
(60.0)\end{array}$ & $<0.01$ \\
\hline $\begin{array}{r}\text { First trimester abortion increases risk of ectopic } \\
\text { pregnancy and/or miscarriage in future } \\
\text { pregnancies }\end{array}$ & $\begin{array}{l}16 \\
(21.6)\end{array}$ & $\begin{array}{l}4 \\
(5.4)\end{array}$ & $\begin{array}{l}5 \\
(33.3)\end{array}$ & \begin{tabular}{|l|l}
4 \\
$(26.7)$
\end{tabular} & $<0.01$ \\
\hline
\end{tabular}




\begin{tabular}{|r|l|l|l|l|l|}
$\begin{array}{r}\text { Risk of serious complication after first trimester } \\
\text { abortion (including transfusion or hospital } \\
\text { admission) is less than 1\% }\end{array}$ & $\begin{array}{r}62 \\
(83.8)\end{array}$ & $\begin{array}{l}64 \\
(86.5)\end{array}$ & $\begin{array}{l}12 \\
(80.0)\end{array}$ & $\begin{array}{l}12 \\
(80.0)\end{array}$ & 0.52 \\
\hline Risk of death from first trimester surgical abortion & 62 & 59 & 10 & 11 & 0.58 \\
is less than 1/1,000,000 & $(83.8)$ & $(79.7)$ & $(66.7)$ & $(73.3)$ & \\
\hline
\end{tabular}

